\title{
Los monstruos de Frankenstein
}

Marina FE

Universidad Nacional Autónoma de México

Frankenstein es la historia de una transgresión. Mary Shelley subtituló su novela The Modern Prometheus haciendo referencia al dios que violó su compromiso con Zeus al otorgarle a los hombres el conocimiento del fuego y con éste la capacidad de raciocinio, sobre todo gracias a la adquisición del lenguaje articulado. Del mismo modo, el doctor Frankenstein, aparente protagonista de la novela, transgrede como Prometeo un orden que la generación romántica veneraba: el orden de la naturaleza (lo que de alguna manera implica también una transgresión en el orden del lenguaje o de la razón hegemónica contemporánea). Al darle vida a un ser vivo de manera artificial, Frankenstein invierte la ley natural de la procreación y al mismo tiempo va más allá de lo que la propia ciencia permite (como bien se lo sugiere su padre muy al principio de la novela). Así, como sujeto racional, está violentando las leyes no escritas de la razón y de la ciencia ya que el conocimiento al que recurre es un conocimiento ilícito, fuera de los límites.

Si bien la literatura romántica pone énfasis en la búsqueda del conocimiento de lo sublime, privilegiando la capacidad de la mente (por encima de la imaginación) para aprehender, por medio de la razón, los profundos misterios del orden natural, en su versión gótica esta búsqueda parece rebasar un límite al situarse más allá del orden mismo de la razón: "the horrifying knowledge here is that the sublime is like a black hole, it drags the subject into its abyss, into its pure negativity" (Mishra 1994: 81.) De esta manera, la visión gótica parecería abandonar todo orden para mostrar el lado oscuro de la razón, el otro lado de un universo ajeno, incomprensible y amenazante. En consecuencia, mientras la búsqueda sublime por excelencia es la de la belleza, la búsqueda gótica está del lado de lo horrible, lo obsceno y lo inefable (unheimlich): el mundo ya no parece susceptible de ser comprendido y controlado mediante la razón y por la "sublime" capacidad de abstracción de la mente, y se presenta como un mundo caótico, desarticulado. En este contexto, los individuos se descubren marginados e incapaces de en- 
tender y dominar esas mismas fuerzas naturales, tanto exteriores como interiores, y esta experiencia puede convertirse en el origen del horror.

Desde esta perspectiva, la literatura gótica puede considerarse como la otra cara del romanticismo sublime, ya que en lugar de pretender convertirse en la expresión de lo bello busca más bien explorar la dimensión prohibida de lo grotesco. De acuerdo con Bajtin, en el romanticismo el grotesco adquiere un nuevo sentido:

Sirve, entonces, para expresar una visión del mundo subjetivo e individual, muy alejada de la visión popular y carnavalesca de los siglos precedentes [...] A diferencia del grotesco de la Edad Media y del Renacimiento [...] el grotesco romántico es un grotesco de cámara, una especie de carnaval que el individuo representa en soledad, con la conciencia agudizada de su aislamiento. [...] El universo del grotesco romántico se presenta generalmente como terrible y ajeno al hombre. El mundo se transforma de pronto en mundo exterior. Y lo acostumbrado y tranquilizador revela su aspecto terrible (1974: 39-41).

En su importante libro Literary Women, Ellen Moers describe el gótico como aquel género de ficción que tiene que ver con el miedo, con la intención de asustar, de poner los pelos de punta, de provocar reacciones físicas de terror. Moers pone el acento en el aspecto fisiológico de estas sensaciones, en su efecto sobre el cuerpo, y esto no es casual en la medida en que la narrativa gótica, debido a su inmediata relación con lo grotesco, siempre tiene que ver con lo corporal, logrando incluso "hacer hablar al cuerpo". De aquí la importancia que se le ha dado en una novela como Frankenstein, así como en otras del llamado gótico femenino, a la problematización de la maternidad y del conflicto femenino frente al recién nacido ("the trauma of the afterbirth", lo llama Ellen Moers). El enfoque de Moers a Frankenstein se concentra "in the motif of revulsion against newborn life, and the drama of guilt, dread and flight surrounding birth and its consequences" (1985: 93), y resulta pertinente por tres razones: en primer lugar porque la propia Mary seguramente se consideraba culpable por el hecho de que su madre hubiera muerto a causa de su nacimiento; en segundo lugar porque, antes de escribir esta obra, ella misma acababa de perder a su propia hija que tenía apenas unos meses de nacida y, además, al momento de escribir estaba de nuevo embarazada; en tercer lugar, por ser mujer y tener un cuerpo de mujer condenado a la maternidad desde los dieciséis años.

Por otra parte, como el monstruo sin nombre, Mary Shelley muy bien podía considerarse a sí misma agente de destrucción al mismo tiempo que víctima del abandono de su progenitora y, como Victor Frankenstein, ella 
también era creadora, primero de niños que se le morían y luego de creaturas aberrantes como su libro, creaciones contra-natura ("my hideous progeny", como ella misma llama al libro en su introducción de 1831), engendros de la imaginación que, como el monstruo de Frankenstein, ponen en crisis cierto orden. La novela se convierte en una prueba de fuego para Mary como creadora, esta vez no de niños sino de libros, un reto y también una suerte de transgresión. Mary podría identificarse aquí con Victor Frankenstein al crear esta "aberración" a partir de una inversión de roles: el hombre que se atreve a dar a luz a un ser vivo (prerrogativa femenina) y la mujer que se atreve a escribir (privilegio masculino), y ambos crean monstruos. Pero también podría identificarse a Mary con el monstruo, víctima y victimario, cuya mera existencia es un escándalo, ya que, como dice en la introducción, ella no se atreve a hablar de sí misma: "I did not make myself the heroine of my tales. Life seemed too commonplace an affair as regards myself" (1991: xvii), pero sí puede hacerlo a través de su personaje. $Y$ es que en esta novela los personajes se confunden peligrosamente al enmarcarse y entretejerse diferentes historias: la de Walton y su relación con Victor Frankenstein, ambos compartiendo ambiciones desmesuradas; la de Frankenstein y su monstruo ilustrado, su doble maligno; la de Frankenstein y su propia autora, ambos creadores de engendros; la de Mary con su propio monstruo...

Un monstruo que no merece siquiera tener un nombre, está por definición fuera del orden, y ese orden es, "naturalmente", el orden patriarcal. Frankenstein crea un monstruo y al hacerlo se convierte a su vez en una suerte de monstruo, en un "overreacher" debido a su transgresión de las leyes naturales y de la ley del padre. Por su parte, Mary también es transgresora al pretender escapar por medio de la escritura a la condición femenina, a la sujeción al cuerpo y a las definiciones sociales de género para apropiarse, como lo hace el monstruo, del lenguaje. Sin embargo, producto del deseo del otro, en este caso del marido, Frankenstein le debe en parte a éste el derecho de nacer:

Shelley urged me to develop the idea at greater length. I certainly did not owe the suggestion of one incident, not scarcely of one train of feeling, to my husband, and yet but for his incitement it would never have taken the form in which it was presented to the world. From this declaration I must except the preface. As far as I can recollect, it was entirely written by him (xxvi).

Así, en el prólogo a Frankenstein, Mary parecería querer rechazar su autoría, o en todo caso declararla como ilegítima: "Women frequently 
prefaced their work with advertisements that proleptically disclaimed any literary merit, ambition or ability [...] writing was something for which the woman writer needed to apologize" (Freeman 1997: 76-77).

En esta novela, el texto narrativo tiene la estructura de las cajas chinas en la medida en que encontramos una narración dentro de otra y dentro de otra más. El texto de "superficie", el del explorador Walton que escribe a su hermana el progreso de su viaje de exploración al Polo Norte, se inscribe perfectamente del lado de lo sublime: se trata del relato de una búsqueda de conocimientos fascinantes y también muy útiles a la ciencia. La naturaleza a la que tendrá que enfrentarse es, al principio, deslumbrante y poco amenazante. Sin embargo, su encuentro con Frankenstein y la historia que éste habrá de narrarle, lo harán descubrir otra naturaleza, la naturaleza interior del ser humano, profundamente oscura e insondable. Si bien las cartas de Walton a su hermana son el marco de la historia que presenta al lector el aspecto más positivo de la búsqueda de lo sublime, el propio relato de Victor Frankenstein también tiene como origen una búsqueda de conocimientos semejante ya que, como científico, busca traer a la luz del entendimiento humano secretos fundamentales que habrían permanecido ocultos. No obstante, el proceso creativo que al principio aparece con signo positivo va transformándose en una empresa de orden negativo al pretender Frankenstein usurpar el papel natural de la mujer como dadora de vida: "The creation itself is [...] the moment of the sublime; in collapsing the two domains of the formation of the subject - sexual and social reproduction and production - through the 'artificial womb', Victor Frankenstein pushes the sublime to its very limits" (Mishra 1994: 216).

Así, la creación del científico, su creatura, será un producto monstruoso que no podrá pertenecer al orden de lo sublime sino que será catapultado al universo grotesco. Lo mismo podría decirse del texto mismo de Mary Shelley que pone en cuestión la definición social de las mujeres como madres, así como el papel tradicional de los hombres como padres.

La novela, estructurada a la manera de círculos concéntricos, lleva al lector de la superficie sublime al centro más oscuro y grotesco donde se encuentra el relato del monstruo, como si se tratara de un hoyo negro hacia el cual todos los acontecimientos se precipitan. Este ser sin nombre, la principal víctima en esta historia, queda condenado a la exclusión, a la exterioridad, al rechazo de todos, y su narración busca expresar la experiencia de la otredad: "In place of the sublime as the 'absolutely great', we now meet the sublime as the extremities of human experience, as the distorted reflection of one's own self, as the apocalyptic side of the living man" (Mishra 1994: 219). En su relato en primera persona, el monstruo narra su experiencia a 
Frankenstein, su creador, con quien se encuentra por fin cara a cara y a quien reprocha haberlo creado para después aborrecerlo: "Remember that I am thy creature; I ought to be thy Adam, but I am rather the fallen angel, whom thou drivest from joy for no misdeed" (84). Lo más importante en esta historia terrible es sin duda el hecho de que el monstruo haya aprendido a hablar, elocuente y persuasivamente como lo hace con Victor, siendo el lenguaje lo que aparentemente le permite escapar a su naturaleza monstruosa pero que en realidad lo aprisiona. De acuerdo con Peter Brooks:

A monster is that which cannot be placed in any of the taxonomic schemes devised by the human mind to understand and to order nature. It exceeds the very basis of classification, language itself: it is an excess of signification, a strange byproduct or leftover of the process of making meaning. It is an imaginary being who comes to life in language and, once having done so, cannot be eliminated from language (1993: 218).

Gracias al uso del lenguaje, el monstruo es capaz de entender su situación de exterioridad, de no-pertenencia, así como su propia monstruosidad, y de reprocharle a su creador el haberlo creado como un ser condenado a la soledad. No obstante, parecería que más que su paternidad ilegítima y antinatural, lo que en última instancia le reclama es no haber tenido una madre. Resulta interesante entonces descubrir en esta novela una notable ausencia de madres vivas: la madre de Frankenstein muere de fiebre escarlatina; Félix y Agata también son huérfanos de madre, lo mismo que Safie, y por supuesto el propio monstruo, y la maternidad, la capacidad de dar vida a otro ser, parece concentrarse exclusivamente en la figura del científico. Así, de acuerdo con Brooks, "the radically absent body of the mother more and more appears to be the 'problem' that cannot be solved in the novel" (1993: 210).

El tema de la maternidad resulta entonces central en Frankenstein, a pesar de ocultarse detrás de la historia del monstruo y de la paternidad. Y es que si Victor Frankenstein no puede ser otra cosa que una especie de padre para el monstruo, el acto mismo de la creación lo acerca al papel biológicamente asignado a las mujeres. No es casual que inmediatamente antes de enfrentar a su creatura, tenga un sueño donde su novia y su madre se confunden:

I thought I saw Elizabeth, in the bloom of health, walking in the streets of Ingolstadt. Delighted and surprised, I embraced her, but as I imprinted the first kiss on her lips, they became livid with the hue of death; her features appeared to change, and I thought that I held the 
corpse of my dead mother in my arms; a shroud enveloped her form, and I saw the grave-worms crawling in the folds of the flannel (43).

Estas dos mujeres tan importantes en la vida afectiva de Victor se convierten en una sola en un sueño discretamente erótico y obviamente tanático que resulta además premonitorio, ya que, más adelante en la novela, la madre morirá a causa de una enfermedad que le contagiará la misma Elizabeth. Es como si a partir de su acto transgresor, el mismo Frankenstein hubiera propiciado la destrucción de las mujeres que lo rodeaban.

Al morir la madre de Victor, la única madre en la novela, queda sólo un objeto que la representa y que cumple en la narración una función clave: es el retrato que el monstruo encuentra colgando del cuello del hermano pequeño del doctor, a quien éste asesina y que, en un arranque de odio, deja en el bolsillo de Justine para inculparla así de su propio crimen: "the murder I have committed because I am forever robbed of all that she could give me, she shall atone. The crime had its source in her; be hers the punishment!" (128). Ésta es sin duda una declaración muy sospechosa ya que no queda claro si la que podría haberle dado afecto es la madre del retrato o la propia Justine, a quien el monstruo no había visto nunca y a la cual parece culpar como la responsable de su propia desgracia, soledad y desamparo.

Other women in the novel hardly exist as characters and, in terms of the plot, appear mainly in order to get killed; their very presence warns of impending death. Murky and phantasmal, the mother is rather a presiding, haunting presence than an active participant in the drama, perceptible in the implicit issues with which the novel deals: giving birth in both a literal and a literary sense (Wolstenholme 1993: 55).

Como en otras novelas góticas, en Frankenstein las mujeres son víctimas de algún héroe-villano que en este caso parecería haberse desdoblado en los personajes del científico y su creatura. Sólo que en este caso, tanto el doctor como el monstruo resultan a su vez víctimas el uno del otro lo mismo que culpables de la muerte de tantos otros personajes, particularmente las mujeres. De acuerdo con Fred Botting, estos desdoblamientos sugieren: "a critique of the Gothic implications of the distinctly masculine Romantic imagination, of a humanism grown monstrous as a result of excessive and exclusive aspirations to power and ideal unity...", por lo que la novela "while presenting the destructive effects on family, gender and social relations, does not end with either an affirmation of domestic values or a moral reprimand. Monstrosity has left the novel open, its frames broken: all boundaries are 
left in question, divided between the positions of Frankenstein and the monster" (1999: 105).

Mary Shelley transgrede así las convenciones del género como existían hasta entonces mediante un juego de espejos en donde no solamente los dos protagonistas masculinos son reflejo uno del otro sino donde ella misma, como creadora de semejante engendro, también se identifica con el propio doctor, como si adelantándose a Flaubert quisiera decirnos: "Frankenstein, c'est moi". Ella sería entonces ese moderno Prometeo, o Prometea, que ha osado apropiarse de la sublime herramienta del lenguaje para entregárnosla en su versión profana.

Obras citadas

Bajtin, Mijail. 1974. La cultura popular en la Edad Media y Renacimiento. Barcelona: Barral Editores.

Botting, Fred. 1999. Gothic. The New Critical Idiom. Londres: Routledge.

Brooks, Peter. 1993. Body Work: Objects of Desire in Modern Narrative. Cambridge: Harvard University Press.

Freeman, Barbara Claire. 1997. The Feminine Sublime. Berkeley: University of California Press.

Mishra, Vijay. 1994. The Gothic Sublime. Albany: State University of New York Press.

Moers, Ellen. 1985. Literary Women. Nueva York: Oxford University Press.

Shelley, Mary. 1991. Frankenstein. Nueva York: Bantam Books.

Wolstenholme, Susan. 1993. Gothic (Re)Visions. Writing Women as Readers. Nueva York: State University of New York Press. 